\title{
"Naturalness" in Designated Wilderness: Long-Term Changes in Non-Native Plant Dynamics on Campsites, Boundary Waters, Minnesota
}

\author{
Holly A. Eagleston and Jeffrey L. Marion
}

Wilderness areas in the United States are preserved for their untrammeled naturalness and opportunities for unconfined recreation. The Boundary Waters Canoe Area Wilderness has these qualities, but long-term recreation visitation pressures on campsites can cause significant ecological changes. This article explores changes on campsites, specifically examining non-native plant ecology over 3 decades. The research replicates a 1982 study analyzing vegetation composition and cover on campsites and environmentally paired controls. Camping activities have removed substantial tree cover on campsites, altering their ecological conditions and perceived wilderness character. Over the span of 32 years, the number of non-native plant species found on campsites has not risen, although their mean relative cover has increased significantly and they have spread to more sites. Of the 23 non-native herbs and grasses found on the campsites, only Cirsium arvense is considered a noxious weed by the state of Minnesota. Other noninvasive, non-native plants fall into a gray area in the context of "naturalness" for an area protected as Wilderness because they provide some positive ecological services even as they degrade wilderness character. Thus, wilderness managers face a difficult challenge in coping with the long-term impacts of visitor use on wilderness conditions and character.

Keywords: wilderness character, non-native plants, recreation ecology, campsite management, long-term changes

$\mathrm{T}$ We Wilderness Act of 1964 established the US National Wilderness Preservation System, which has grown to include nearly 108.9 million ac (44.1 million ha), accounting for $17 \%$ of all federally owned public land and $5 \%$ of the all US lands. Under this legislation, managers are to preserve natural ecosystems that are untrammeled and provide opportunities for solitude and unconfined recreation that leave them "unimpaired for future use and enjoyment as wilderness" (16 U.S. \$\$ 1131-1136). Wilderness management emphasizes natural stewardship (Hendee and Dawson 2002), but as wilderness visitation intensifies and associated resource impacts accumulate, managers are frequently compelled to apply corrective actions.

Recreation visitation may be a threat to wilderness condition and values because of the adverse ecological effects caused by it or done by managers to accommodate it. The introduction and dispersal of non-native plants in wilderness pose a threat because they have direct and indirect ecosystem effects that compromise ecological integrity (Randall 2000, Pickering and Mount 2010). Recreation visitation and non-native plant invasions are intertwined in protected natural areas because visitors are often the vectors for introducing and dispersing many non-native plants, which occur primarily on trails and recreation sites (Pickering and Hill 2007, Morgan and Carnegie 2009).

One of the tenets of the Wilderness Act is to manage for "naturalness," but its meaning is open to interpretation. Naturalness can mean an ecosystem lacking intentional human control, a pristine system free of human effects, or an ecosystem where managers actively maintain or restore historical conditions (Cole and Yung 2010). The presence and management of non-native plants in wilderness areas reflect this ambiguity. These plants are often unintentionally introduced and dispersed by wilderness visitors as seeds attached to their equipment or clothing (Marion et al. 1986, Whinam et al. 2005, Pickering and Mount 2010, Ansong and Pickering 2013). The most common non-native plant species on wilderness campsites and trails are also common to suburban lawns, including dandelion (Taraxacum officinale), plantain (Plantago spp.), and clover (Trifolium spp.). Thus, such species are often familiar to visitors as "weeds" and their presence in wilderness may diminish their perceptions of being in pristine wilderness.

Manuscript received June 7, 2017; accepted August 15, 2017; published online September 28, 2017.

Affiliations: Holly A. Eagleston (hollye1@vt.edu),Virginia Tech University, 310 W. Campus Drive, Blacksburg, VA 24061. Jeffrey L. Marion (jmarion@vt.edu), US Department of the Interior, US Geological Survey and Virginia Tech University.

Acknowledgments: This study waspartially funded by the US Geologic Survey and the USFS, Superior National Forest. We thank Claire Underwood and Jeff Feldhaus for their dedicated assistance collecting field data. Use of trade, product, or firm names is for descriptive purposes only and does not imply endorsement by the US Government. 
Not all non-native plants have undesirable effects, and a few of these species have characteristics allowing them to be highly invasive. Non-native invaders tend to have traits that enable them to outcompete native plants in disturbed settings. Traits include trampling resistance, fast growth rates, high seed production, and adaptability to a wide range of environments (Alpert et al. 2000, Alpert 2006, Pyšek and Richardson 2010, Van Kleunen et al. 2010). Many non-native species only colonize frequently visited disturbed areas; few can outcompete native plants in undisturbed settings, particularly under shady forest canopies (Marion et al. 2016). Across national parks in Australia, non-natives species were recorded within $20 \mathrm{~m}$ of the trail edge, with a rapid decrease in abundance occurring with increasing distance (Ngugi et al. 2014). Dickens and others (2005) found non-native plants only within $1 \mathrm{~m}(3.28 \mathrm{ft})$ of portage trails in the US Boundary Waters Canoe Area Wilderness (BWCAW). Morgan and Carnegie (2009) found 32 non-natives species within $328 \mathrm{ft}(100 \mathrm{~m})$ of backcountry huts in subalpine zones of the Australian Alps.

Some non-native plants can invade and displace native species, altering system productivity, diversity, and stability. Of particular concern is when non-native invasive species are able to invade undisturbed areas (Marion et al. 1986, Pickering and Hill 2007). Barros and Pickering (2014) reported that 21 non-native plants found in Argentina's Aconcagua Provincial Park spread from recreation sites to undisturbed locations. Land managers are increasingly conducting non-native plant inventories and developing policies to prevent their introduction and dispersal within wilderness areas (Cole and Landres 1996, Randall 2000).

Allen and others (2009) report 20,305 non-native species infestations in a National Park Service (NPS) database, with 3,756 unique species totaling 18 million ac (7.3 million ha) in 216 parks. Regression analyses of variables accounting for variation in non-native species richness revealed kilometers of backcountry trails and park visitation as the most influential factors. Westbrooks (1998) notes that the NPS has initiated approximately 448 invasive plant control projects and that units such as Glacier National Park are experiencing great difficulty controlling aggressive invasive species such as spotted knapweed (Centaurea stoebe) and leafy spurge (Euphorbia esula) that are also invading undisturbed areas of the park.

\section{Study Area}

Designated in 1964, the BWCAW is a US Forest Service (USFS)-managed 1,090,000-ac (441,107-ha) area in northeastern Minnesota. Visitors have canoed, portaged, and camped throughout this area for many decades, and managers seek to perpetuate this traditional and historical mode of recreation (Landres et al. 2015). There are more than 1,000 lakes, approximately 80 entry points, 18 hiking trails, and 1,200 $\mathrm{mi}(1931 \mathrm{~km})$ of canoe trails in the BWCAW. The area receives more than 250,000 visitors each year, and the USFS restricts use through a permit season with entry-point quotas. A central challenge for BWCAW management is interpreting the meanings of naturalness and untrammeled nature for a designated wilderness where recreational activities such as canoeing and camping traditions are an inextricable part of the area's historical and cultural values.

The USFS maintains more than 2,000 campsites in the BWCAW, each with a primitive pit toilet and steel fire grate. A core resource protection objective is to manage these long-term designated campsites to maintain their natural conditions and limit resource impacts. The purpose of this study is to examine long-term trends for non-native plants on a large sample of BWCAW campsites over a 32-year period. Objectives include evaluating vegetation change on campsites over time, quantifying long-term changes in species richness and non-native plants on campsites and undisturbed control areas, and investigating the BWCAW qualities of wilderness character given the long-term human-environment interactions.

\section{Methods}

This study replicates Marion's recreation ecology doctoral study of 96 wilderness campsites and paired control areas (Marion 1984). Campsites were selected through stratified random sampling, in which sites were equally distributed among three use levels and five ecological land types. Since 1982, 10 campsites have been closed and 5 were omitted because their conditions were substantially altered by windthrow or wildfire. Eighty-one sites from the original 1982 study were remeasured in 2014 using the same protocols.

All campsites were located within the USFS Kawishiwi District of the Superior National Forest located near Ely, Minnesota. Study area soils were derived from glacial deposits, covering a thin mantle of glacial-till and lacustrine sediments (Prettyman 1987). The area receives between 66 and $78 \mathrm{~cm}$ of precipitation per year, with $40 \%$ falling as snow. Primary plant communities include the jack pine forest (Pinus banksiana) associated with red pine (Pinus resinosa); the Great Lakes pine forest dominated by white pine (Pinus strobus) and red pine ( $P$. resinosa) associated with paper birch (Betula papyrifera); and the northern boreal hardwood-conifer forest dominated by trembling aspen (Populus tremuloides), paper birch (B. papyrifera), balsam fir (Abies balsamea), black spruce (Picea mariana), and northern white cedar (Thuja occidentalis) (Moyle and Moyle 1977).

Campsite area was measured based on visually obvious trampling-related disturbance to vegetation and organic litter. Campsites included adjacent satellite tenting spots and excluded any internal pockets of undisturbed vegetation. For each campsite, a circular control plot of $538 \mathrm{ft}^{2}\left(50 \mathrm{~m}^{2}\right)$ was also assessed in a nearby undisturbed area. Plot size was determined based on the calculations of a species area curve for the four most common BWCAW plant community types using the nested-plot technique with 12 plot sizes ranging from 10.7 to $3,229.2 \mathrm{ft}^{2}\left(1-300 \mathrm{~m}^{2}\right)$. Each control plot was environmentally similar to the campsite it was paired with; it had the same soil type, ecological land type, aspect, slope, soil depth to bedrock, and distance to water.

Vegetation sampling was completed using a modified quadrat method with whole-area determinations for the campsites and controls. All plants were identified to species and their cover estimates were recorded as $1=$ Solitary, $0.5 \%$ cover; $2=$ Few plants, $1 \%$ cover; $3=$ Numerous, with cover $2-5 \% ; 4=$ Cover $6-25 \% ; 5=$ Cover 26-50\%; $6=$ Cover 51-75\%; and $7=$ Cover $>75 \%$ after Braun-Blanquet, 1965). The number of trees and seedlings on campsites were tallied and divided by campsite size to obtain density measures (trees/hectare). Coverage values were aggregated by growth habit to obtain campsite cover estimates for tree, shrub, herbaceous, and grass cover. Coverage estimates were assessed for bare soil, exposed bedrock, organic litter, sparse vegetation (5-50\% plant cover), and dense vegetation (51-100\% plant cover). Relative cover for plants was determined by dividing the species coverage by the percentage of ground vegetation cover for each campsite. Areal coverage in square meters of each plant species was also determined on campsites by multiplying the percentage cover by campsite size. Areal measures of vegetation loss and exposed soil were calculated by 


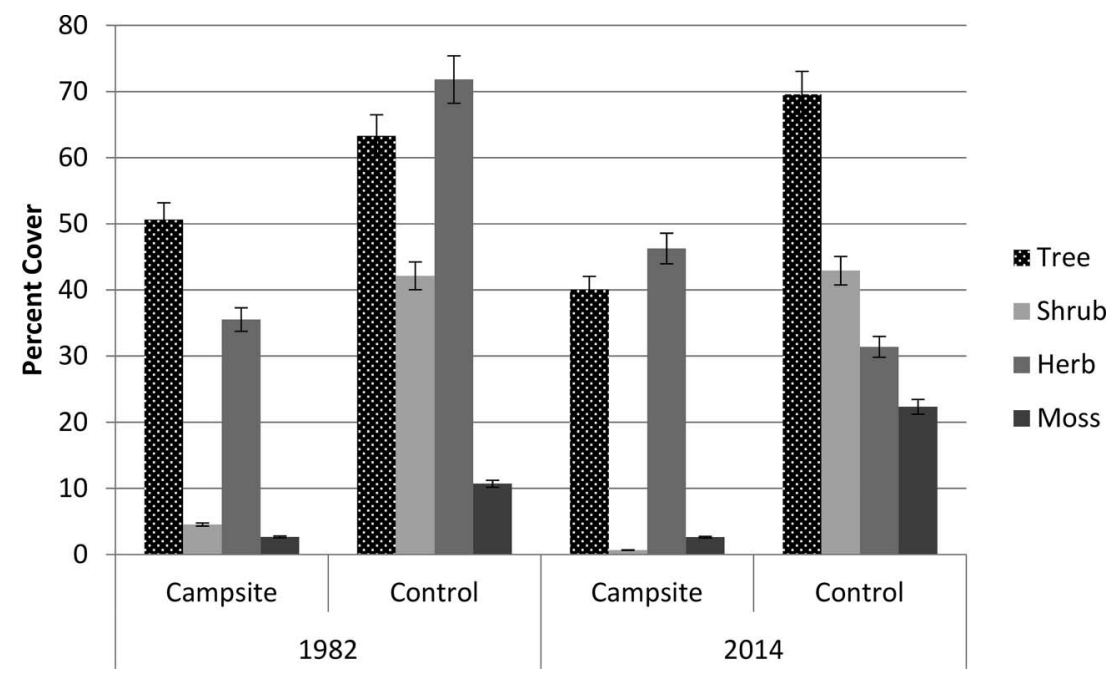

Figure 1. Vegetation cover on campsite and control areas from 1982 to 2014.

Table 1. Effect of tree cover on plant richness and relative cover on campsites in 2014.

\begin{tabular}{|c|c|c|c|c|c|}
\hline \multirow[b]{2}{*}{ Indicator } & \multicolumn{3}{|c|}{ Campsite tree cover } & \multirow[b]{2}{*}{$F$ ratio } & \multirow[b]{2}{*}{$P$ value } \\
\hline & Low $(<26 \%)(n=27)$ & Medium $(26-50 \%)(n=23)$ & High $(>50 \%)(n=31)$ & & \\
\hline Species richness $(n)$ & $17.85( \pm 4.9)^{*}$ & $16.5( \pm 3.3)$ & $14.6( \pm 3.9)$ & 4.41 & 0.015 \\
\hline Non-native species $(n)$ & $5( \pm 2.0)$ & $4.3( \pm 2.1)$ & $2.9( \pm 4.5)$ & 8.01 & $<0.001$ \\
\hline Non-native species, relative cover (\%) & $3.1( \pm 2.0)$ & $7.4( \pm 20.4)$ & $2.8( \pm 2.5)$ & 1.37 & 0.260 \\
\hline
\end{tabular}

Note: * Standard deviation.

multiplying percentage cover estimates by campsite size. In 2014, soil loss on campsites and canoe landings was also assessed by measuring depth of soil erosion by comparing the undisturbed areas to bottom of eroded campsite and erosion along the lakeshore at canoe landings. Depths were multiplied over the mapped surface area of disturbance to determine aggregate soil loss.

Longitudinal 1982-2014 comparisons were made and statistically analyzed with paired $t$ tests of campsite-to-campsite and control-to-control measurements. To examine current recreation activity impacts, the 2014 campsite values were compared to their paired control values using paired $t$ tests, data were tested for normal distribution, and outliers were removed. A one-way analysis of variance (ANOVA) was used to investigate the relative influence of tree cover on vegetative indicators. SAS JMP software was used for all statistical tests.

\section{Results}

Open and active use of the campsites over 32 years has caused a marked divergence in the ecological conditions on campsites compared with surrounding control areas. Control areas experienced a significant decrease in herbaceous cover and an increase in tree and moss cover (Figure 1). Campsites experienced reductions in tree and shrub cover with a corresponding increase in herbaceous cover.

Significant reductions in tree cover occurred from 1982 to 2014. Figure 1 shows mean tree cover on campsites declined by $10.5 \%$ from 1982 to $2014(P=0.004)$. Tree regeneration is threatened by harvesting of trees by visitors for firewood; 65 trees/ha $(P=0.031)$ were lost on campsites from 1982 to 2014 (Eagleston and Marion 2017). Loss of tree cover and regeneration has led to an increase of sunlight on campsites, allowing herbaceous species to thrive, increasing in cover from $36.2 \%$ to $46.5 \%$ over 32 years $(P=0.019)$.
Additional environmental dynamics associated with the loss in tree cover were tested with ANOVA after creating three classes of campsite tree cover: low (0-25\%), medium (26-50\%), and high (51-100\%). Campsites with lower tree cover in 2014 had higher species richness and numbers of non-native plants (Table 1). The trend in higher species diversity with low tree cover is also evident over time, with campsites in 2014 showing $4.9 \pm 2.6$ more species per site than in $1982(P=0.032)$.

The number of non-native plant species found on BWCAW campsites has remained the same at 21 , although the average number of non-native plants per site has risen from 1.8 to 4.0 (Table 2). Over 32 years, non-native plants have had time to disperse to more campsites. Non-native plants were found on 55 campsites (67.9\%) in 1982, expanding to 74 campsites (91.4\%) in 2014 (Figure 2). The number of non-native plants stayed the same or decreased on 22 campsites over the 32-year period (Figure 2). However, whereas non-native plants were not found in any control plots in 1982, three non-native species, including T. officinale, Plantago major, and $H i$ eracium caespitosum, were found in control plots in 2014.

Although the number of non-native plant species per campsite has increased with time, the relative cover has not. Neither the mean cover nor relative cover of non-native species changed significantly from 1982 to 2014 (Table 2). The mean cover is the average cover estimate of non-natives for the site; the relative cover adjusts the cover of non-native species to the amount of vegetation cover present on the site.

Visitor activities on campsites perpetuate a disturbed environmental setting where vegetation is trampled and organic litter is pulverized and lost, with eventual exposure of underlying mineral soils (Marion et al. 2016). Introduced European earthworms used as live bait in fishing can also have a large impact on the loss of leaf 
Table 2. Non-native species abundance in BWCAW.

\begin{tabular}{|c|c|c|c|c|c|c|}
\hline \multirow[b]{2}{*}{ Indicator } & \multicolumn{2}{|c|}{2014} & \multicolumn{2}{|c|}{1982} & \multirow{2}{*}{$\begin{array}{l}\text { Mean difference } 2014 \\
\text { camp-1982 camp }\end{array}$} & \multirow[b]{2}{*}{$P$ value } \\
\hline & Camp & Control & Camp & Control & & \\
\hline Non-native species $(n)$ & 21 & 3 & 21 & 0 & 0 & - \\
\hline Non-native species/site $(n)$ & 4.0 & 0.04 & 1.8 & 0 & $2.2( \pm 0.3)^{*}$ & $<0.001$ \\
\hline Sites with non-natives species (\%) & 91.4 & 3.7 & 67.9 & 0 & 23.5 & - \\
\hline Mean plant cover of non-natives/site (\%) & 7.9 & 0.03 & 11.2 & 0 & $-3.3( \pm 2.7)$ & 0.211 \\
\hline Mean relative cover of non-natives/site (\%) & 16.1 & 0.05 & 21.7 & 0 & $-5.6( \pm 4.5)$ & 0.212 \\
\hline
\end{tabular}

Note: * Standard deviation.

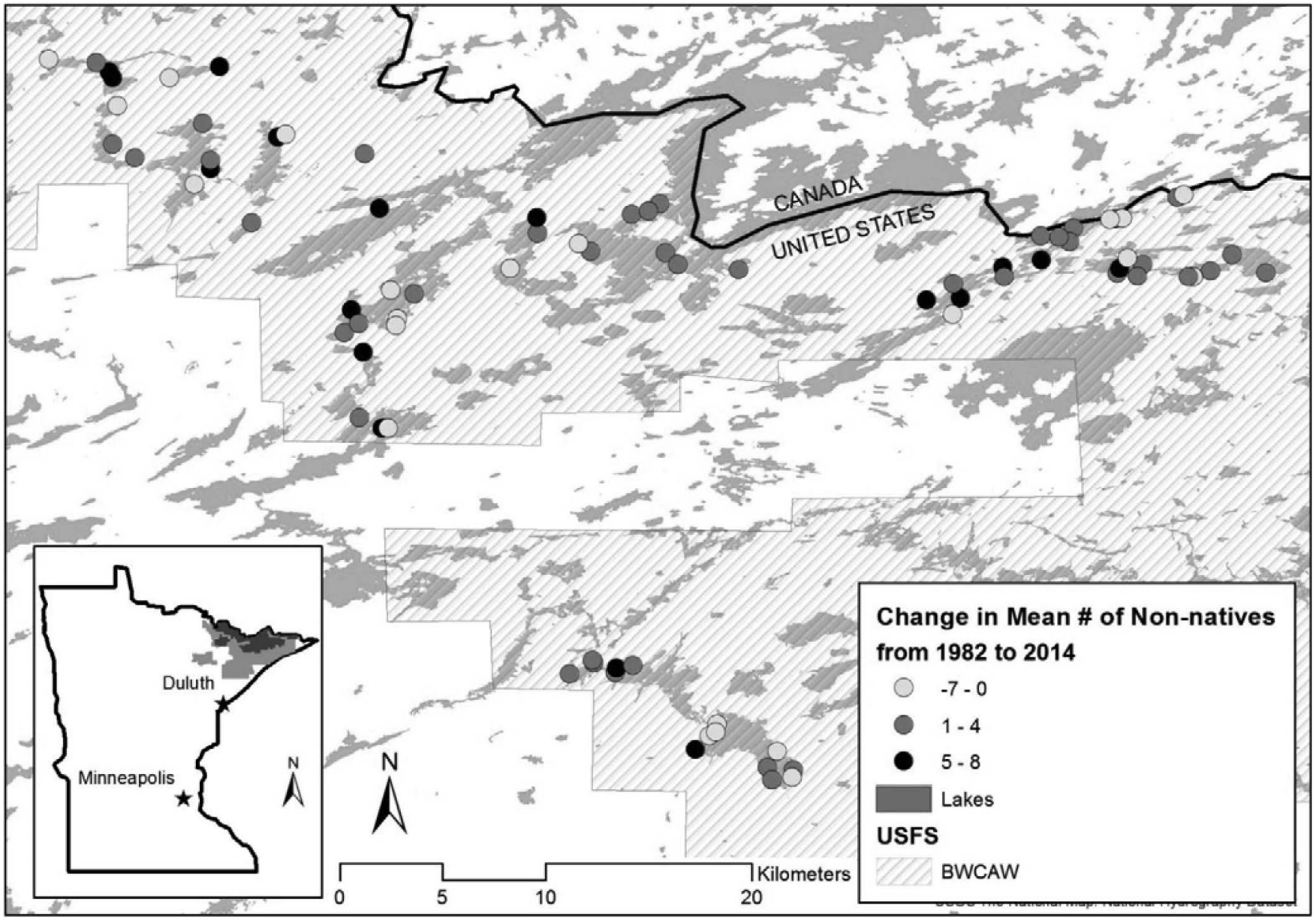

Figure 2. Map illustrating changes in mean number of non-native plants found on BWCAW campsites from 1982 to 2014.

litter, another agent in the exposure of mineral soil (Bohlen et al. 2004, Hale et al. 2005). From 1982 to 2014, campsite organic litter cover declined by $15.4 \%$, exposed soil increased $8.3 \%$, and vegetation cover increased $16.8 \%$. The exposure of soil on campsites often leads to soil erosion, which is considered the most significant and irreversible form of recreation impact (Marion et al. 2016). Mean soil loss on 2014 campsites was estimated at $607 \mathrm{ft}^{3}\left(17.2 \mathrm{~m}^{3}\right)$. Non-native species made up $16.1 \%$ of the vegetation cover, and without them, soil loss likely would have been greater. Reductions in tree and shrub cover (Figure 1) allowed the shade-intolerant herbaceous plants, mostly graminoids that were noted in 2014, to colonize less-trafficked peripheral areas and/or replace more fragile native herbaceous plants. Graminoids have been shown to be significantly more resistant and resilient to trampling pressures than broad-leafed herbaceous species (Cole 1995a). Table 3 shows the change in relative cover for each non-native species from 1982 to
2014. Many species lost relative cover in 2014, including Agrostis alba (-18.8\%), Trifolium repens (-12.3\%), Festuca rubra (-10.4\%), and $P$. major (-7.6\%). Relative cover increased for other species, particularly Bromis inermis (39.9\%). Some non-native species were found at more campsites, but their areal cover in square meters did not change appreciably from 1982 to 2014 (Table 3). For example, T. officinale increased from 29 to 64 campsites but relative cover declined $4.9 \%$ and areal cover decreased by $\left(522 \mathrm{ft}^{2}\right.$ or $\left.48.5 \mathrm{~m}^{2}\right)$. From the perspective of areal cover, Trifolium procumbens increased substantially $\left(6,210 \mathrm{ft}^{2}\right.$ or $\left.577 \mathrm{~m}^{2}\right)$ whereas two species exhibited marked decreases- - T. repens $\left(-7,405 \mathrm{ft}^{2}\right.$ or $\left.-688 \mathrm{~m}^{2}\right)$ and Phleum pretense $\left(-2,852 \mathrm{ft}^{2}\right.$ or $\left.-265 \mathrm{~m}^{2}\right)$.

Of the non-native species found in BWCAW, the expansion of plants classified as noxious weeds are of particular concern. Cirsium arvense is a prohibited noxious weed in the state of Minnesota and is actively controlled by USFS staff (Alexander et al. 2013). Although 
Table 3. Changes in cover of non-native species.

\begin{tabular}{|c|c|c|c|}
\hline Non-native plant species & $\begin{array}{c}\text { Difference } \\
\text { in cover } \\
(\%)\end{array}$ & $\begin{array}{l}\text { Difference } \\
\text { in relative } \\
\text { cover }(\%)\end{array}$ & $\begin{array}{c}\text { Difference in } \\
\text { areal cover } \\
\mathrm{ft}^{2}\left(\mathrm{~m}^{2}\right)\end{array}$ \\
\hline \multicolumn{4}{|l|}{ Herbs } \\
\hline Achillea millefolium & 6.3 & -1.2 & 0.0 \\
\hline Capsella bursa-pastoris & 6.9 & -1.9 & $-37.7(-3.5)$ \\
\hline Cerastium vulgatum & 13.3 & -4.5 & $-416.5(-38.7)$ \\
\hline Chenopodium album* & -1.0 & -3.5 & 0.0 \\
\hline $\begin{array}{l}\text { Chrysanthemum } \\
\text { leucanthemum }\end{array}$ & 20.3 & 1.2 & $721.2(67.0)$ \\
\hline Cirsium arvense & 5.3 & -3.7 & $92.6(8.6)$ \\
\hline Hieracium aurantiacum & 9.0 & 5.2 & $899.8(83.6)$ \\
\hline Hieracium caespitosum ${ }^{* *}$ & 19.8 & 2.2 & $554.3(51.5)$ \\
\hline Plantago major & 34.3 & -7.6 & $-603.8(-56.1)$ \\
\hline Polygonum aviculare & 5.1 & -0.3 & $68.9(6.4)$ \\
\hline Prunella vulgaris & 4.3 & -0.9 & $44.1(4.1)$ \\
\hline Ranunculus acris & 2.7 & 0.6 & $78.6(7.3)$ \\
\hline Rumex acetosella** & 1.2 & 3.8 & $130.2(12.1)$ \\
\hline Taraxacum officinale & 42.6 & -4.9 & $-522(-48.5)$ \\
\hline Trifolium aureum ${ }^{* *}$ & 3.7 & 1.6 & $55.9(5.2)$ \\
\hline Trifolium pratense & -2.7 & -3.0 & $-52.7(-4.9)$ \\
\hline Trifolium procumbens & 1.4 & 3.5 & $6,206.4(576.6)$ \\
\hline Trifolium repens & 24.4 & -12.3 & $-7,409.9(-688.4)$ \\
\hline \multicolumn{4}{|l|}{ Grasses } \\
\hline Agropyron repens & -0.1 & -6.0 & $-47.4(-4.4)$ \\
\hline Agrostis alba & -0.8 & -18.8 & $-900.9(-83.7)$ \\
\hline Bromis inermis & 1.6 & 39.9 & $645.8(60.0)$ \\
\hline Festuca rubra* & -2.1 & -10.4 & $-396.1(-36.8)$ \\
\hline Phleum pratense & -6.1 & -6.4 & $-2,849.2(-264.7)$ \\
\hline Mean & 9.3 & -1.03 & $-162.5(-15.1)$ \\
\hline Standard error & 2.9 & 2.61 & $455.3(42.3)$ \\
\hline$P$ value & 0.003 & 0.349 & 0.362 \\
\hline
\end{tabular}

Note: * Only found in 1982.

** Only found in 2014.

\# Invasive.

the relative cover decreased from 1982 to 2014, its areal coverage on 81 campsites increased by $93 \mathrm{ft}^{2}\left(8.6 \mathrm{~m}^{2}\right)$. C. arvense was found on one campsite in 1982 and in 2014 it was found on six campsites, some up to $14.3 \mathrm{mi}(23 \mathrm{~km})$ away from the site it was found on in 1982. Hieracium aurantiacum and $H$. caespitosum are both rated as having potential to cause moderate ecological damage and are on the USFS watch list (Alexander et al. 2013). H. caespitosum was not found at all in 1982, but in 2014 it covered $549 \mathrm{ft}^{2}\left(51 \mathrm{~m}^{2}\right)$ on 16 campsites. $H$. aurantiacum increased $5.2 \%$ in relative cover in 2014, covering $899 \mathrm{ft}^{2}\left(83.6 \mathrm{~m}^{2}\right)$ on 16 campsites.

\section{Discussion}

\section{Are Non-Natives in the BWCAW an Ecological Threat?}

Although non-native species are not desirable, they are not necessarily detrimental unless they show clear harm to the environment (Sagoff 2005). Loss of species richness, alteration of biogeochemical processes, and undermining ecological integrity are all viable causes of environmental harm (Callaway and Aschehoug 2000, Pysek et al. 2004). Non-native species that are considered truly harmful have been defined as "invasive" when they are capable of transport, colonization, establishment, and self-sustaining and naturalized (Theoharides and Dukes 2007). Their ability to outcompete and replace native plants in undisturbed settings is a key factor of concern. Some invasive plants have the potential to spread over large distances and cause impact to the environment, economy, or health (Richardson et al. 2011).

Only 1 of the 21 non-native species found on BWCAW campsites is considered noxious. The Minnesota Noxious Weed Law (MN Statutes 18.75-18.91) lists Canada thistle, C. arvense, as a noxious weed and calls for the control of maturation and spread of propagating parts. The cover of $C$. arvense increased only by $93 \mathrm{ft}^{2}$ $\left(8.6 \mathrm{~m}^{2}\right)$ on the 81 campsites from 1982 to 2014 . It was not found in adjacent off-site control areas.

Trace occurrences of non-native species were found on only 3 of 81 control plots, which are proximate to campsites and receive occasional trampling traffic. In our judgment, these species are not causing ecological harm and none appear able to outcompete native plants in undisturbed settings. Many of the non-natives found on campsites, such as dandelion (T. officinale) and clover (Trifolium spp.), are shade intolerant; they do best in sunny, disturbed settings. Tree cover has been reduced on campsites over 32 years whereas the control areas have experienced an increase in tree cover as the forest has matured. The disturbance-associated non-native forbs and grasses found on BWCAW campsites are rarely able to survive in shaded off-site areas and have difficulty competing with native plants in offsite settings. The non-native species have not become invasive on campsites either. In 2014, 16.1\% of the vegetation cover found on campsites was non-native, and this proportion has fallen from $21.7 \%$ since 1982 (Table 2). Trampling pressure from visitors and competition from native grasses are likely the predominant factors limiting the cover of these non-native species.

Although the cover of non-native species has been relatively consistent, there has been an increase in the mean number of non-native species per campsite from 1982 to 2014. The most commonly found non-native species on campsites during both survey years were $P$. major, $T$. officinale, and $T$. repens. These are common lawn weeds that visitors are likely introducing or dispersing from campsite to campsite as seeds on their equipment and clothing (Pickering and Mount 2010). Figure 2 shows that there is not a clear spatial pattern in the change of mean number of non-native species found on campsites. As a Leave No Trace practice, visitors can be asked to check and remove seeds from tents, gear, clothing, and shoes before outdoor trips and before leaving campsites each day (Marion 2014).

We note that non-native plants may also provide some benefits or ecosystem services by protecting wilderness campsites from soil loss. Marion et al. (1986) note that "the presence of these disturbance-associated exotics is fortuitous, as they partially protect the soil from erosion as well as contribute some organic matter that helps maintain the soil structure." Thus, efforts to eradicate non-natives from campsites would reduce campsite vegetation cover, which aids in binding the soil and lessening water and wind soil loss. Non-native plants may continue to establish and fill in bare ground on campsites, which could further limit soil erosion on campsites. As noted in other studies, non-natives can provide ecological services and may help colonize disturbed areas, creating conditions for native plants to come in (Rai 2013, Rai 2015).

\section{Management of Non-Native Plants in the Context of Wilderness}

The Wilderness Act prescribes a goal of maintaining the natural and untrammeled quality of wilderness areas after their establishment. From this study, it is clear that environmental conditions on campsites have markedly changed since the BWCAW's 1964 designation. What is not clear is whether these changes constitute trammeling or degradation of the natural qualities for which the BWCAW was established, which also included the cultural heritage and traditions of canoeing and camping. In the context of non-native plants, managers are faced with the dilemma of whether to remove species that do not belong there or leaving them because they provide useful ecological services that protect campsite soils from erosion. 
The meaning of "untrammeled" in the Wilderness Act has been discussed at length (Cole and Yung 2010). The idea of Wilderness is to have areas that are allowed to operate without the forces of man's manipulation (Zahniser 1963). As Lucas (1973) stated, if the ecological processes are uncontrolled, then the results are desirable. If we forego the notion that recreation sites are "sacrifice sites" and uphold these areas to the same standards as the rest of the wilderness, then in the context of BWCAW, there are two actions that should be considered a "manipulation." One is the presence of non-native plants and the other is the loss of tree cover. Large numbers of non-native plants were introduced to the area during the logging era and from numerous cabins and resorts that predated wilderness designation (Marion 1984). In the 1982 campsite study substantially greater numbers of non-native plants were found on campsites that had been placed on old logging camps and cabin and resort sites (Marion 1984).

This study found the numbers and relative cover of non-native species to be relatively unchanged over the last 3 decades. What did change was an increase in the mean number of non-native plants found on each campsite in the BWCA (see Table 3 for list of species). However, there is little evidence that non-native plants are able to spread into undisturbed forested settings; they are restricted to disturbed campsites. We conclude that the great majority of these species do not pose a large-scale ecological threat to the Wilderness.

The other manipulation is the loss of tree cover that has occurred on campsites, largely because of the cutting of trees for firewood (Marion 1984). Camping introduces disturbance pressure on woody vegetation when mature trees and saplings are lost from visitor-related damage, root exposure, and felling for firewood. Managers have done limited plantings of native trees on campsites in an effort to replace lost trees. However, with staffing levels at record lows and increasing visitation, trampling pressures, and visitors continuing to fell trees for firewood, the long-term success of replacing trees on campsites is low. Natural tree regeneration on campsites rarely occurs, and only in small pockets of vegetation protected from traffic by rocks or a grouping of mature trees (Marion 1984).

Hendee and Dawson (2002) make the point that wilderness management is an intellectual dilemma in which we try not to influence wilderness. However, the more people learn about and visit wilderness, and the more managers manipulate physical conditions within wilderness, the less wild it becomes. Recreationists appear to be the primary vector for the continued introduction and dispersal of non-native plants to wilderness campsites; therefore, they are a natural focus for resolving problems with the spread of non-native species. More active measures could be taken to minimize the further spread of noxious weeds throughout BWCAW campsites. Leave No Trace practices can address the inspection and removal of seeds from gear, clothing, and footwear and can promote firewood-gathering practices that do not involve woods tools and damage to or felling of trees. Otherwise, campsites will continue to lose their tree cover, contrasting more strongly with the undisturbed forest surrounding BWCAW campsites.

\section{Conclusion}

Management of non-native plants poses a dilemma to the values associated with wilderness. Trying to control non-native species means asserting human control over the ecosystem, which conflicts with core wilderness management objectives. However, not doing so leaves traces of human effect because non-natives were primarily introduced by humans. Cole and Yung (2010) state that the emer- gence of wilderness values of unconfined, unfettered, unrestrained, and untrammeled natural areas places more importance on freedom from human control than being free from human effect. Although the presence of non-natives is "unnatural," they are a symptom of unintentional manipulation of the environment by the action of people simply visiting wilderness areas; removing them would represent exerting additional human control over the ecosystem. At the same time, the presence of non-natives on campsites provides ecological services by increasing biodiversity and plant cover and stabilizing erosion, thereby increasing campsite sustainability. In the case of the BWCAW, non-native species are providing an ecological service; most are not invasive, do not spread outside of disturbed areas, and were a part of the ecosystem when the Wilderness was first established because of the long history of human exploration, visitation, and commercial activities.

We suggest that the continued loss of campsite trees strongly diminishes the perceived naturalness of campsites. Managers will need to deliberate the acceptability of long-term tree loss on campsites and accept it, increase abatement efforts, enhance their prior treeplanting and protection efforts on campsites, or implement a campsite closure and replacement program when a campsite loses most or all of its trees (Marion 2016). Furthermore, although efforts should be taken to stop the introduction and dispersal of invasive species, we suggest that managers consider accepting the presence of noninvasive non-native plants on campsites. They are rarely able to disperse into offsite areas, and their presence on campsites provides plant cover that lessens soil loss. This recommendation is based on the species pool we have documented in this study. The new standard of what is natural embraces the idea of "novel" ecosystems (Schlaepfer et al. 2011) that recognizes that human interaction with the environment has occurred for many years and being a part of the ecosystem ourselves, by interacting with it, we change irrevocably it. If we embrace the concept of novel ecosystems, and accept them in the context of naturalness and untrammeled in Wilderness areas, then we could have ecosystems with higher functionality and higher resiliency to work in concert with human disturbance.

\section{Literature Cited}

AleXander, S., ED. 2013. Final Environmental Impact Statement: BWCAW Non-native Invasive Plant Management Project. USDA Forest Service, Superior National Forest, Duluth, MN. 90 p.

Allen, J.A., C.S. Brown, AND T.J. STOHLGREN. 2009. Non-native plant invasions of United States National Parks. Biol. Invasions 11(10): 2195-2207. doi:10.1007/s10530-008-9376-1.

ALPERT, P. 2006. The advantages and disadvantages of being introduced. Biol. Invasions 8(7):523-1534. doi:10.1007/s10530-005-5844-z.

AlPERT, P., E. BONE, AND C. HOLZAPFEL. 2000. Invasiveness, invasibility and the role of environmental stress in the spread of non-native plants. Perspect. Plant Ecol. 3(1):52-66. doi:10.1078/1433-8319-00004.

ANSONG, M., AND C. PiCKERING. 2013. Long-distance dispersal of Black Spear Grass (Heteropogon contortus) seed on socks and trouser legs by walkers in Kakadu National Park. Ecol. Manag. Restor. 14(1):1-4. doi:10.1111/emr.12021.

BARROS, A., AND C. PICKERING. 2014. Non-native plant invasion in relation to tourism use of Aconcagua Park, Argentina, the highest protected area in the Southern Hemisphere. Mt. Res. Dev. 34:13-26. doi: 10.1659/MRD-JOURNAL-D-13-00054.1.

Bohlen, P., Scheu, S., Hale, C., Mclean, M., Migge, S., Groffman, P., AND D. PARKINSON. 2004. Non-native invasive earthworms as agents of change in northern temperate forests. Front. Ecol. Environ. 2(8):427-435. Available at www.jstor.org/stable/3868431. 
CALlaway, R., AND E. Aschehoug. 2000. Invasive plants versus their old and new neighbors: A mechanism for exotic invasion. Science 290(5491): 521-523. doi:10.1126/science.290.5491.521.

COLE, D. 1995. Experimental trampling of vegetation. I. Relationship between trampling intensity and vegetation response. J. Appl. Ecol. 32:203-214. doi:10.2307/2404429.

Cole, D. N., AND P.B. LANDRES. 1996. Threats to wilderness ecosystems: impacts and research needs. Ecol. Appl. 6(1):168-184.

COlE, D., AND L. YUNG. 2010. Beyond naturalness: Rethinking park and wilderness stewardship in an era of rapid change. Island Press, Washington, DC. 287 p.

DiCKENS, S., F. GERHARDT, AND S. COLLINGE. 2005. Recreational portage trails as corridors facilitating non-native plant invasions of the Boundary Waters Canoe Area Wilderness. Conserv. Biol. 19(5):1653-1657. doi: 10.1111/j.1523-1739.2005.004285.x.

EAgleston, H., AND J. Marion. 2017. Sustainable campsite management: Long-term ecological changes on campsites in the Boundary Waters Canoe Area Wilderness, MN. J. Nat. Conserv. 37:73-82. doi: 10.1016/j.jnc.2017.03.004.

Hale, C., Frelich, L., AND P. Reich. 2005. Exotic European earthworm invasion dynamics in northern hardwood forests of Minnesota, USA. Ecol. Appl. 15(3):848-860. doi:10.1890/03-5345.

HendeE, J., AND C. Dawson. 2002. Wilderness management: Stewardship and protection of resources and values, 3rd ed. Fulcrum, Golden, CO. $637 \mathrm{p}$.

Landres, P., C. Barns, S. Boutcher, T. Devine, P. Dratch, A. LindHOlm, L. Merigliano, N. RoePer, AND E. Simpson. 2015. Keeping it wild 2: An updated inter-agency strategy to monitor trends in wilderness character across the National Wilderness Preservation System. USDA Forest Service, Gen Tech. Rep. RMRS-GTR-340, Rocky Mountain Research Station, Fort Collins, CO. 114 p.

LUCAS, R.C. 1973. Wilderness: A management framework. J. Soil Water Conserv. 28:150-154.

MARION, J. 2014. Leave no trace in the outdoors. Stackpole Books, Mechanicsburg, PA.

Marion, J., D. Cole, And S. Bratton. 1986. Exotic vegetation in wilderness areas. P. 114-120 in Proc. of the National Wilderness Research Conference: Current research, July 23-26, 1985, Lucas, R.C. (comp.). USDA Forest Service, Gen. Tech. Rep. INT-212, Fort Collins, CO.

Marion, J., Y.F. Leung, H. Eagleston, And K. Burroughs. 2016. A review and synthesis of recreation ecology research findings on visitor impacts to wilderness and protected natural areas. J. For. 114(3): 352-362. doi:10.5849/jof.15-498.

MARION, J.L. 1984. Ecological changes resulting from recreational use: A study of backcountry campsites in the Boundary Waters Canoe Area Wilderness, Minnesota. PhD Dissertation, Univ. of Minnesota, Department of Forest Resources, Minneapolis, MN. 279 p.

MARION, J.L. 2016. A review and synthesis of recreation ecology research supporting carrying capacity and visitor use management decision-making. J. For. 114(3):339-351. doi:10.5849/jof.15-062.

MinNesota Noxious WeEd LAW, MN STAT. \$\$ 18.75-18.91 (2016).

MORGAN, J. W., AND V. CARNEGIE. 2009. Backcountry huts as introduction points for invasion by non-native species into subalpine vegetation. Arct. Antarct. Alp. Res. 41(2): 238-245.

MOYLE, J. B., AND E. W. MOYLE. 1977. Northland wildflowers: the comprehensive guide to the Minnesota region. University of Minnesota Press, Minneapolis.

NGugi, M., V. Neldner, AND R. Dowling. 2014. Non-native plant species richness adjacent to a horse trail network in seven National Parks in southeast Queensland, Australia. Australas. J. Env. Man. 21(40): 413-428. doi:10.1080/14486563.2014.952788.

PICKERING, C., AND W. HiLL. 2007. Impacts of recreation and tourism on plant diversity and vegetation in protected areas in Australia. J. Environ. Manage. 85(4):791-800. doi:10.1016/j.jenvman.2006.11.021.

Pickering, C., AND A. MounT. 2010. Do tourists disperse weed seed? A global review of unintentional human-mediated terrestrial seed dispersal on clothing, vehicles and horses. J. Sustain. Tour. 18(2):239-256. doi:10.1080/09669580903406613.

Prettyman, D. H. 1987. Soil survey of Kawishiwi area, Minnesota: parts of Lake and Cook Counties in Superior National Forest. U.S. Department of Agriculture Soil Conservation Service, Washington, D.C.

PyšeK, P., D.M. Richardson, M. RejmáneK, G.L. Webster, M. WilLIAMSON, AND J. KirSCHNER. 2004. Alien plants in checklists and floras: Towards better communication between taxonomists and ecologists. Taxon 53(1):131-143. doi:10.2307/4135498.

PYŠEK, P., AND D.M. RiCHARDSON. 2010. Invasive species, environmental change and management, and health. Annu. Rev. Env. Resour. 35: $25-55$.

RAI, P.K. 2013. Plant invasion ecology: Impacts and sustainable management. Nova Science Publisher, New York. 196 p.

RAI, P.K. 2015. Paradigm of plant invasion: Multifaceted review on sustainable management. Environ. Monit. Assess. 187:759. doi:10.1007/ s10661-015-4934-3.

RANDALL, J.M. 2000. Improving management of nonnative invasive plants in wilderness and other natural areas. P. 64-73 in Proc.: Wilderness science in a time of change, May 23-27, 1999, Missoula, MT. Vol. 5: Wilderness ecosystems, threats, and management, Cole, D.N., S.F. McCool, W.T. Borrie, and J. O'Loughlin (comps.). USDA Forest Service, Proceedings RMRS-P-15-Vol-5, Rocky Mountain Research Station, Ogden, UT.

Richardson, D.M., P. PyšEK, AND J.T. CARLTON. 2011. A compendium of essential concepts and terminology in invasion ecology. P. 409-420 in Fifty years of invasion ecology: The legacy of Charles Elton. WileyBlackwell, Oxford, UK.

SAGOFF, M. 2005. Do non-native species threaten the natural environment? J. Agric. Environ. Ethics 18(3):215-236. doi:10.1007/s10806-0051500-y.

SChlaepfer, M., D. SAX, AND J. Olden. 2011. The conservation value of non-native species. Conserv. Biol. 25(3):428-437. doi:10.1111/j. 1523-1739.2010.01646.x.

TheOHARIDES, K., AND J. DuKes. 2007. Plant invasion across space and time: Factors affecting nonindigenous species success during four stages of invasion. New. Phyt. 176(2):256-273. doi:10.1111/j.1469-8137. 2007.02207.x.

VAn Kleunen, M., E. Weber, AND M. FisCher. 2010. A meta-analysis of trait differences between invasive and non-invasive plant species. Ecol. Lett. 13(2):235-245. doi:10.1111/j.1461-0248.2009.01418.x.

WestbroOKS, R.G. 1998. Invasive plants: Changing the landscape of America. Federal Interagency Committee for the Management of Noxious and Exotic Weeds, Paper 490, US Government Documents, Utah Regional Depository), Logan, UT. 125 p.

Whinam, J., N. ChilcotT, And D.M. Bergstrom. 2005. Subantarctic hitchhikers: Expeditioners as vectors for the introduction of alien organisms. Biol. Conserv. 121(2):207-219. doi:10.1016/j.biocon. 2004.04.020.

ZAHNISER, H. 1963. Editorial: Guardians not gardeners. The Living Wilderness 83(2). 